\title{
CONTRADITÓRIO E INVALIDAÇÃO ADMINISTRATIVA NO ÂMBITO DA ADMINISTRAÇÃO PÚBLICA FEDERAL
}

\author{
VLADIMIR DA ROCHA FRANÇA*
}

1. Introdução - 2. Considerações sobre o Processo Administrativo -

3. Contraditório no Processo Administrativo - 4. Sobre a Exigibilidade do Contraditório na Invalidação Administrativa - 5. Considerações Finais.

\section{I - Introdução}

O Estado brasileiro tem passado por profundas reformas, tanto no plano constitucional como no plano infraconstitucional, para se ajustar as novas demandas da sociedade. Ainda que as diretrizes políticas desse projeto padeçam de profunda polêmica e de repúdio por considerável parcela da doutrina nacional, o seu impacto jurídico é inegável nas relações entre o Poder Público e os cidadãos.

Não se consolidou ainda o novo perfil que se quer conferir a administração pública. Os efeitos sociológicos das modificações sofridas pelo regime jurídico-administrativo encontram-se bem nebulosos, restando ao jurista tentar compreender as novas normas e institutos que foram incorporados ao conjunto de preceitos retores do exercício da função administrativa.

Uma das gratas surpresas das recentes inovações legislativas foi a satisfação de uma reivindicação antiga dos estudiosos do direito administrativo: temos, finalmente, um diploma legislativo que regula o procedimento (ou processo) administrativo no âmbito da administração pública federal, a Lei n 9.784 , de 29 de Janeiro de 1999.

O novo diploma legal federal, em seu art. 53, incorporou expressamente preceito que já vinha sendo reconhecido tanto pela doutrina como pela jurisprudência, no sentido de reconhecer a legitimidade da Administração para invalidar os seus próprios atos.

Não raras vezes, o exercício dessa prerrogativa da Administração acarreta em prejuízo para o administrado, intervindo em situação jurídicas que o beneficiava.

* Mestre em Direito Público pela Faculdade de Direito do Recife (UFPE). Doutorando em Direito do Estado pela PUC/SP. 
Não raras vezes, a Administração exerce tal poder sem verificar se há ou não boa fé nos efeitos jurídicos gerados pelo ato administrativo viciado, ignorando totalmente a própria estabilidade de suas relações com o administrado.

O arbítrio no exercício dessa prerrogativa acaba produzindo mais prejuízos para o Estado do que a própria permanência do ato administrativo viciado dentro do regime jurídico-administrativo, quebrando a confiança do administrado na ação administrativa. Embora artifícios maliciosos existam para que mau administrador burle decisão judicial favorável ao administrado, fundada na responsabilidade estatal, a conta não deixa de chegar.

No art. $5^{\circ}$, inciso LV, da Lei Maior, prescreve-se que "aos litigantes, em processo judicial ou administrativo, e aos acusados em geral são assegurados o contraditório, com os meios e recursos a ele inerentes". Estaria a Administração, quando prestes a invalidar os seus próprios atos, necessariamente obrigada a comunicar previamente os administrados tal intenção?

Essa é a indagação que norteia o presente trabalho.

\section{2 - Considerações sobre o Processo Administrativo}

\section{$2 . l$ - Processualidade na função administrativa}

O Estado, para atingir suas finalidades, necessita da expedição de normas concretas. Através dessa normas, há a concretização dos preceitos estatuídos pela lei.

Cabe a função administrativa a determinação formação das situações jurídicas individuais que deverão ser regidas pelo preceito normativo proposto no texto legal, finalizando sua concretização normativa através de uma norma de decisão, o ato administrativo'.

Os atos administrativos são normas concretas que têm por finalidade constituir, modificar ou extinguir uma relação jurídica administrativa ${ }^{2}$. Mas essas normas não surgem do nada.

Toda a atividade do Estado é caracterizada pela processualidade 3 . Para exercer seu poder, necessita o Estado do emprego de uma seqüência ordenada de atos e de fatos jurídicos para expressar sua "vontade funcional" 4 . Sem a processualidade, não há manifestação normativa.

1 Cf. Vladimir da Rocha França. Invalidação Judicial da Discricionariedade Administrativa, Recife, 1998, p. 20.

2 Cf Celso Antônio Bandeira de Mello. Curso de Direito Administrativo, $11^{*}$ ed., São Paulo, Malheiros, p. 272; e Lúcia Valle Figueiredo, Curso de Direito Administrativo, $4^{\mathbf{a}}$ ed., São Paulo, Malheiros, pp. 150-151 Vladimir da Rocha França, op. cit., p. 87.

3 Carlos Ari Sundfeld. “A Importância do Procedimento Administrativo", in: Revista de Direito Público, $\mathrm{n}^{\circ}$ 84/1997, pp. 66-68.

4 Idem, ibidem p. 67. 
A processualidade demonstra o caráter dinâmico da atividade estatal, o momento de sua realização. Há processualidade quando o sistema jurídico demanda, para a expedição de uma norma jurídica estatal, uma sucessão encadeada e necessária de atos e fatos jurídicos - todos correlacionados ao resultado final - impulsionada por pessoas ou órgãos também juridicamente interligados entre $\mathrm{si}^{5}$.

Pode-se dizer que a processualidade é a fonte próxima da norma estatal.

Cada função estatal tem sua processualidade. Em virtude da controvérsia que padece a terminologia empregada para designá-la, vamos tentar empregar um critério que possa melhor refletir esse fenômeno, quando o Estado brasileiro exerce a função administrativa.

\section{2 - Procedimento e processo administrativo}

A Constituição Federal, em diversos pontos, emprega a expressão "processo administrativo". Aliás, foi o termo preferido na Lei Federal n 9.784/99. Embora "processo" normalmente seja identificado com a função jurisdicional, a doutrina e a jurisprudência mais recente têm entendido que a expressão pode também ser utilizada para indicar a processualidade da função administrativa ${ }^{6}$

Dentro da processualidade administrativa, temos o procedimento administrativo, consistente na sucessão encadeada e necessária de atos e fatos jurídicos que deve preceder o ato administrativo. É possível, em se tratando de função administrativa, que excepcionalmente apenas um ato jurídico seja suficiente para introduzir a norma no sistema?.

Se a sequiência demanda a participação dos destinatários do ato administrativo, temos o processo administrativo. O processo administrativo, portanto, é uma espécie de procedimento administrativo.

Não há um critério unânime, na doutrina, para fixar a distinção entre processo e procedimento ${ }^{8}$. Contudo, o critério adotado é o que melhor, a nosso ver, reflete a acepção de "processo" constitucionalmente fixada.

O processo é um instrumento para a democratização do exercício do poder. Através do processo, permite-se ao cidadão participar da construção das normas

5 CF Odete Medauar. A Processualidade no Direito Administrativo, São Paulo Ed. RT, 1993, pp. 23-28. Usamos "pessoa" para nos reportarmos a entes dotados de personalidade jurídica.

6 Ver STJ, ROMS n 8116-SC, Rel. Min Gilson Dipp, Quinta Turma, unânime pelo não provimento, julgado em 16.09.99, publicado no DJ de 11.10.99.

7 Cf. Mônica Martins Toscano. "O Ato Administrativo e seus Requisitos Procedimentais", in. Revista Trimestral de Direito Público, $\mathrm{n}^{\circ}$ 18/1997, pp. $211-212$ e 229; e Lúcia Valle Figueiredo, Curso..., cit., p. 404; e José Cretella Júnior, Prática do Processo Administrativo, $3^{\circledR}$ ed., São Paulo, Ed. RT, 1999, p. 37.

8 Ver Antônio Carlos de Araújo Cintra, Ada Pellegrini Grinover e Cândido Rangel Dinamarco, Teoria Geral do Processo, 8 ed., São Paulo, Ed. RT, 1991, pp. 247-255. Para uma crítica à expressão "processo administrativo", ver Carlos Ari Sundteld, op. cit., pp. 72-73; e Mônica Martins Toscano op. cit., pp. 214-216. 
jurídicas que irão reger sua vida social. Há um processo legislativo, autorizando o cidadão, através de seus representantes, a opinar sobre o conteúdo das leis; há um processo jurisdicional, que confere ao cidadão o direito de buscar e participar na resolução dos conflitos em que esteja envolvido; e, por fim, um processo administrativo, revelando a Administração para os administrados, por viabilizar a participação destes no que antecede a expedição das decisões administrativas.

Importante assinalar lição de Carlos Ari Sundfeld ${ }^{9}$ sobre essa matéria, ao lembrar que a lei, a sentença e o ato administrativo não estão imediatamente condicionados ao assentimento do particular, sendo:

"(...) o processo a contrapartida que se assegura à liberdade pelo fato de o ato de autoridade ser unilateral, dentro da proposta de resguardar o equilíbrio entre a liberdade e a autoridade. Sem que o ato estatal deixe de ser ato de autoridade e, portanto, imperativo, se permite o exercício da liberdade: condicionando a produção do ato a um processo regulado do qual o indivíduo possa participar. Sob este ângulo, o processo cumpriria um papel eminentemente ligado à tutela dos direitos individuais".

\section{3 - Devido processo legal administrativo}

O ordenamento jurídico estabelece sua própria processualidade e, em especial seus processos. Ao modelo de processo administrativo prescrito pelo Direito Positivo, denominamos devido processo legal administrativo, para fins de nosso estudo.

$O$ devido processo legal representa o conjunto de princípios e regras constitucionais que devem ser observados pelo Estado em sua processualidade. Essa cláusula constitucional $^{10}$ determina diretrizes que devem ser seguidas pelo Poder Público na produção do direito positivo" ${ }^{1 !}$.

Há forte entendimento doutrinário em favor de uma dupla acepção do devido processo legal em nosso sistema jurídico ${ }^{12}$. Ao lado desse sentido processual, haveria outro, substancial ou material, que aglutinaria o conjunto de princípios e regras que vinculam o próprio conteúdo das normas jurídicas estatais.

No direito positivo estadunidense, esse sentido substancial do due process of law serviu como fundamento para o controle da constitucionalidade das leis. Princípios como isonomia e razoabilidade passaram a ser agregados e justificados em

9 Op. cit., p. 67. Cf. Mônica Martins Toscano, op. cit., p. 213.

10 Ver CF, art. $5^{\circ}$, LIV. Cf. Fernão Borba Franco. "A Fórmula do Devido Processo Legal", in: Revista do Processo, $\mathrm{n}^{\circ}$ 94, p. 94.

11 Os princípios constitucionais são normas hierarquicamente privilegiadas que atribuem imperatividade aos valores e finalidades constitucionais, objetivando o conteúdo destes e, viabilizando sua concretização ( $c f$ Vladimir da Rocha França, "Questões sobre a Hierarquia entre as Normas Constitucionais". in: Revista Trimestral de Jurisprudência, Vol. 168, pp. 117-118).

12 Cf. Lúcia Valle Figueiredo. "Estado de Direito e Devido Processo Legal”, in: Revista Trimestral de Direito Público, $\mathrm{n}^{\circ}$ 15/1996, p. 37; Nelson Nery Júnior, Princípios do Processo Civil na Constituiçāo Federal, São Paulo, Ed. RT, pp. 31-37. 
razão do due process of law, viabilizando a intervenção judicial na substância das decisð̃es legislativas e administrativas do Estado norte-americano ${ }^{13}$.

No caso da administração pública, o devido processo legal substancial englobaria os princípios constitucionais que a regem. Legalidade e moralidade administrativa seriam elementos desse princípio, por exemplo ${ }^{14}$.

Năo negamos o valor metodológico do devido processo legal substancial, pois mediante essa noção, permite-se visualizar os princípios jurídicos da administração pública em interação. Entretanto, a própria tradição do direito positivo brasileiro se encarregou de tornar expressos não apenas as preceitos usualmente identificados com o sentido processual, mas também, com o sentido substancial do due process of law. Bastaria, como diz com propriedade Nelson Nery Júnior ${ }^{15}$, a enunciação da cláusula do devido processo legal para tornar despiciendos os demais incisos do art. $5^{\circ}$ do texto constitucional. E razão assiste também á Lúcia Valle Figueiredo ${ }^{16}$ quando leciona:

"Somente será due process of law aquela lei - e assim poderá ser aplicada pelo Magistrado - que não agredir, não entrar em confronto, não entrar em testilhas com a Constituição, com os valores fundamentais consagrados na Lei das leis."

Quando se menciona a acepção substancial do devido processo legal no direito administrativo, há referência direta ao produto, 0 ato administrativo. No sentido processual, é a processualidade o objeto de incidência.

Como justamente é a processualidade administrativa o campo de nossa investigação, optamos por reservar a expressão devido processo legal administrativo para indicar tão-somente o sentido processual da cláusula, facilitando assim a exposição e compreensão do tema.

Ao devido processo legal administrativo é um imputado todo um plexo de finalidades ${ }^{17}$, cuja essência é justamente a conciliação da atividade administrativa

13 Cf Carlos Roberto de Siqueira Castro. O Devido Processo Legal e a Razoabilidade das Leis na Nova Constituição do Brasil, Rio de Janeiro, Forense, 1989, pp. 3 e 32-33; e Antônio Roberto Sampaio Dória. Direito Constitucional Tributário e Due Process of Law, Rio de Janeiro, Forense, 1986, pp. 26-31; Edward S. Corwin, A Constituiçāo Norte-Americana e seu Significado Atual, trad. p/ Lêda Boechat Rodrigues, Rio de Janeiro, Jorge Zahar Editor, pp. 266-268: Thomas Cooley, Princípios Gerais de Direito Constitucional dos Estados Unidos da América, trad. p/ Alcides Cruz, 2^ ed., São Paulo, Ed. RT, pp. 169-183; e San Thiago Dantas, "Igualdade perante a Lei e due process of law", in: Problemas de Direito Público, Rio de Janeiro, Forense, 1953, p. 43.

$14 C f$. Edward S. Corwin, op. cit., p. 268.

15 Op. cit., p. 37.

16 "Estado...", cit., p. 36. Cf. Dinorá Adelaide Museti Grotti, "Devido Processo Legal e o Procedimento Administrativo", in: Revista Trimestral de Direito Público, $\mathrm{n}^{\circ}$ 18/1997, p. 35: Carlos Ari Sundfeld, op. cit., p. 69: e Thomas Cooley, op. cit. pp. 256-257.

17 Cf. Odete Medauar, op. cit., pp. 61-69; Nagib Slaibi Filho, “O Devido Processo e Lei”, in: Anotações à Constituição de 1988 - Aspectos Fundamentais, 4" ed., Rio de Janeiro, Forense, 1993, 
com os cânones constitucionais. Representa, como dissemos, o modelo constitucional de processo administrativo, que é exigido nas situações previstas pela própria Lei Maior.

Dentre os preceitos retores do devido processo legal administrativo, temos o princípio do contraditório.

Como bem alerta Odete Medauar ${ }^{18}$ :

"(...) o processo administrativo representa um dos meios pelos quais, na atividade administrativa, se concretizam princípios e normas constitucionais; significa, portanto, um núcleo que abriga regras substanciais da atuação administrativa e do ordenamento, de modo conforme aos princípios constitucionais".

Se do ponto de vista do administrado, representa um conjunto de garantias que lhe são constitucionalmente asseguradas, para a Administração, "consiste na obrigatoriedade de atuar mediante processo em determinadas situações" ${ }^{19}$. E na lição de Sérgio Ferraz ${ }^{20}$ :

“(...) somente se pode pensar em efetiva realização do princípio democrático quando (e onde) possa o administrado participar da feitura do querer administrativo, ou da sua concretização efetiva. Para tanto, imprescindível é que se assegure ao cidadão o postular junto à Administração, com a mesma corte de garantias que lhe são deferidas no processo jurisdicional (particularmente, as certezas do contraditório e da publicidade)".

\section{3 - Contraditório no Processo Administrativo}

\section{1 - Noção de contraditório}

O contraditório sempre foi um conceito profundamente relacionado com a cláusula do due process of law, nela presente desde sua primeira formulação ${ }^{21}$. Por injunção expressa da Lei Maior ${ }^{22}$, constitui um preceito aplicável aos processos administrativos.

185 e 194-197; e Thomas Cooley, op. cit., pp. 255-256.

18 Op. cit., p.74.

19 Idem, ibidem, p. 83. Cf. Mônica Martins Toscano, op. cit., p. 217; Nagib Slaibi Filho, op. cit., p. 181; e Carlos Roberto de Siqueira Castro, op. cit., pp. 40-41.

20 Em seu "Processo Administrativo e Constituiçāo Federal", in: Direito Constitucional, Vol. II, Col. Bureau Jurídico, Brasília Consulex, 1998, p. 157. Cf. Mônica Martins Toscano, op. cit., p. 218.

21 Cf. Thomas Cooley, op. cit., p. 343.

22 Ver CF, art. 5, LV. Ver STJ, ROMS n 4393-MT, Rel. Min. Gilson Dipp, Quinta Turma, unânime pelo não provimento, julgado em 21.09.99, publicado no DJ de 18.10.99. 
O princípio do contraditório integra o devido processo legal administrativo, obrigando à Administração a cientificar os administrados sobre a existência e o conteúdo dos processos que versem sobre seus interesses individuais ${ }^{23}$. É reconhecido ao Poder Judiciário o poder de verificar a ação da administração pública sob o prisma do devido processo legal, ainda que não adentre no mérito da decisão administrativaa ${ }^{24}$. Aproveitando a lição de Odete Medauar ${ }^{25}$ :

"Em essência, o contraditório significa a faculdade de manifestar o próprio ponto de vista ou argumentos próprios ante fatos, documentos ou pontos de vista apresentados por outrem."

Como se vê, a idéia do contraditório está bem relacionada com situações potencial ou materialmente litigiosas. Ao se referir a "litigantes" e "acusados em geral", a Constituição procurou incidir o princípio de modo mais amplo possível ${ }^{26}$.

O administrado é litigante quando está em situação de controvérsia com outro administrado - em virtude de um ato administrativo - ou com o próprio Poder Público ${ }^{27}$. Já a expressão "acusados", no âmbito administrativo, abrange "todas as pessoas situações onde há imputação a alguém de falta ou conduta ilícita" 28.

E, mais uma vez, razão assiste à Sérgio Ferraz ${ }^{29}$ :

“(...) Ao se cuidar de processo administrativo, a palavra litigante assume feição diferenciada, apontando não só os que já tenham dissidências instauradas, mas também aqueles que possam a vir a tê-las; ou ainda mais, os que busquem instrumentalizar seus direitos de petição e de representação; e, além deles, os que estejam no desempenho de seu direito público subjetivo (constitucional) de fiscalizar o exercício administrativo (co-participação administrativa)".

23 Cf. Mônica Martins Toscano, op. cit., p. 217.

24 Ver STF, RE n 165680-SC, Rel. Min. Ilmar Galvão, Primeira Turma, unânime pelo provimento, julgado em 28.04.95, publicado no DJ de 15.09.95; STF, MS n²0775-DF, Rel. Min. Oscar Correia, Pleno, unânime pelo indeferimento, julgado em 02/06/88, publicado no DJ de 01.07.88; e STJ, RESP $n^{\circ}$ 208293-CE, Rel. Min. Vicente Leal, Sexta Turma, unânime pelo não conhecimento, julgado em 08.06.99, publicado no DJ de 28.06.99.

25 Op. cit., p. 96. Cf. Dinorá Adelaide Museti Grotti, op. cit., p. 37.

26 Cf. Dinorá Adelaide Museti Grotti, op. cit., pp. 36-37; e Carlos Mário da Silva Velloso, "Princípios Constitucionais do Processo", in: Temas de Direito Público, Belo Horizonte, Del Rey, 1997, p. 230.

27 Odete Medauar, op. cit., pp. 77-78. Ver STF, MS n 22285-SP, Rel. Min. Sydney Sanches, Pleno, unânime pelo indeferimento, julgado em 01.04.96, publicado no DJ 17.05.96.

28 Lúcia Valle Figueiredo, Curso..., cit., p. 405. Ver STF, AGRAG n 186840-RS, Rel. Min. Marco Aurélio, Segunda Turma, unânime pelo não provimento, julgado em 20.03.98, publicado no DJ de 15.05.98.

29 Op. cit., p. 158 (grifo em sublinha no original; grifo em negrito, nosso). Cf. José Cretella Júnior, op. cit., p. 30. 
Admitida a divergência potencial ou presente de interesses, pontos-de-vista e de interpretações jurídicas entre Administração e administrado, deve haver o contraditório $^{30}$. A Administração não perde sua posição de supremacia ao efetivar o contraditório, mas sim observa a obrigação de comunicar ao administrado a contingência de um ato administrativo que pode afetar a respectiva esfera de direitos individuais.

Não concordamos com a lição no sentido de visualizar uma equivalência entre as posiçōes da Administração e administrado quando presente o contraditório, haja vista ser insustentável uma posição de igualdade quando um dos pólos da relação permanece com o poder de expedir unilateralmente norma jurídica vinculante $e$ imperativa para o outro pólo. Afinal, uma das características do regime jurídico-administrativo, decorrente do princípio da prevalência do interesse público, é justamente a posição de supremacia de quem exerce a função administrativa ${ }^{31}$.

O contraditório confere um caráter dialético ao processo administrativo, possibilitando à Administração conhecer a antítese pelo administrado para formar uma síntese (ato administrativo) adequada ao interesse público ${ }^{32}$.

Prestemos atenção a um ensinamento de Cintra, Grinover e Dinamarco ${ }^{33}$ que, embora concebida para o processo judicial, traz-nos preciosos elementos para a compreensão do processo administrativo:

"O juiz, por força de seu dever de imparcialidade, coloca-se entre as partes, mas equiidistantes delas; ouvindo uma, não pode deixar de ouvir a outra; somente assim se dará a ambas a possibilidade de expor suas razões, de apresentar suas provas, de influir sobre o convencimento do juiz. (...) É por isso que foi dito que as partes, em relação ao juiz, não têm papel de antagonistas, mas sim de "colaboradores necessários": cada um dos contendores age no processo tendo em vista o próprio interesse, mas ação combinada dois serve à justiça na eliminação do conflito ou controvérsia que os envolve."

A inexistência de jurisdição administrativa em nosso sistema jurídico não permite a formação da angularidade que caracteriza a relação jurídica processual (judicial). A relação jurídica entre Administração e administrado não deixa de linear quando há o contraditório. Todavia, ainda que atue visando o seu próprio interesse,

30 Odete, Medauar, op. cit., p. 97.

31 Cf. Celso Antônio Bandeira de Mello, op. cit., p. 30. Há defesa no sentido de que as posições jurídicas entre administração pública e administrado são igualadas no processo administrativo. Ver Odete Medauar, op. cit., p. 97; e Elio Fazzalari, "Procedimento e Processo (Teoria Generale)", in: Novíssimo Digesto Italiano, Vol. XIII. Milão, Udet, 1996, p. 827.

32 "Parte-se do suposto de que a verdade só pode ser evidenciada pelas teses contrapostas das partes", como bem leciona José de Albuquerque Rocha (Teoria Geral do Processo, $3^{2}$ ed.. São Paulo, Malheiros, 1996, pp. 51-52).

33 Op. cit., pp. 55-56 (grifo em itálico no original; grifo em negrito, nosso). 
em conjunto com a atividade da Administração, o administrado se torna colaborador do interesse público, viabilizando uma melhor aplicação da lei ao caso concreto ${ }^{34}$.

E seguindo ensinamento de José Cretella Júnior ${ }^{35}$ :

"Não obstante se trate de binômio, não de trinômio (como no direito processual civil), as partes em ação, na realidade são contrapostas (...), defendem não raras vezes interesses antagônicos: os administrados, pleiteando os direitos que a lei lhes faculta, a Administração velando para que os deveres sejam observados, ambos, enfim, em última análise, fornecendo elementos para que a justiça figure sempre em primeiro plano e o Estado atinja do melhor modo o fim elevado a que se propõe realizar."

\section{2 - Desdobramento do contraditório na Lei $n^{\circ} 9.784 / 99$}

\section{2.l. Direito à informaçāo geral}

Como já dito, a Lei $n^{\circ} 9.784 / 99$ veio acolher uma velha reivindicação dos estudiosos do direito administrativo. Padecia o regime jurídico-administrativo de um diploma legislativo que disciplinasse a processualidade da Administração ${ }^{36}$.

Em vários pontos, a lei federal de processo administrativa (LFPA), concedeu mais densidade ao princípio do contraditório.

No art. $2^{\circ}$, caput, da LFPA, estatui-se expressamente o princípio do contraditório como princípio da Administração, que já estava previsto no art. $5^{\circ}$, inciso LV, da Lei Maior.

O princípio do contraditório determina à Administração o respeito ao direito do administrado à informação geral, que lhe confere a prerrogativa de examinar os fatos que estão na formação do processo e demais dados, documentos e provas que surgirem em seu curso ${ }^{37}$. $\mathrm{O}$ administrado tem o direito à ciência da tramitação dos processos administrativos em que tenha a condição de interessado, bem como de acesso aos autos, à obtenção de cópias de documentos nele contidos e, ainda, às decisões proferidas ${ }^{38}$.

Aliás, constitui critério a ser observado pela Administração a "garantia dos direitos à comunicação, à apresentação de alegações finais, à produção de provas e

34 Cf. Odete Medauar, op. cit., pp. 102-103.

35 Op cit., p. 40

36 Cf. Odete Medauar, op. cit., pp. 137-157.

37 Odete Medauar, op. cit., p. 104. Cf. Héctor Jorge Escola, Teoria General del Procedimiento Administrativo, s/loc, s/d, pp. 145-146; Mônica Martins Toscano, op. cit., pp. 218-219; e Dinorá Adelaide Museti Grotti. op. cit., p. 38.

38 Ver LFPA, art. $3^{\circ}$, III; e art. 46. Ver STJ, ROMS n 9946-DF, Rel. Min. Edson Vidigal, Quinta Turma, unânime pelo não provimento, julgado em 17.08.99, publicado no DJ de 20.09.99; e STJ, MS 6045-DF, Min. Hélio Mosimann, Primeira Seção, maioria pela concessão da segurança, julgado em 26.05.99, publicado no DJ de 27.09.99. 
à interposição de recursos, nos processos de que possam resultar sanções e nas situações de litígio" ${ }^{39}$.

A LFPA ${ }^{40}$ limita o direito à informação geral, ao não permitir o acesso do administrado aos dados e documentos de terceiros protegidos por sigilo decorrente da segurança nacional ou da proteção constitucional à privacidade, à honra e à imagem.

\subsubsection{Direito à audiência}

Outra decorrência do princípio do contraditório é o direito do administrado de ser ouvido, ou seja, de poder se manifestar sobre todos os elementos apresentados no processo administrativo pela Administração ou por outros administrados ${ }^{41}$. Assegurado esse direito, fortalece-se a regularidade do processo administrativo ${ }^{42}$.

Essa faculdade do administrado está implícita entre os vários dispositivos que regulam a fase instrutória do processo administrativo ${ }^{43}$. Em especial, o art. $41 \mathrm{da}$ LFPA, que determina a sua intimação para se pronunciar sobre a prova ou diligência determinada pela autoridade competente; e o art. 44 do mesmo diploma legal, ao estabelecer que encerrada a instrução, tem o interessado o direito de se manifestar no prazo máximo de dez dias, caso outro prazo não tiver sido fixado em lei.

\subsection{Contraditório e ampla defesa como princípio jurídico unificado: o amplo contraditório}

Como preceitos bastantes próximos, doutrina abalizada não raras vezes procura fundir os princípios do contraditório e da ampla defesa em um só $\sigma^{44}$. Lúcia Valle Figueiredo ${ }^{45}$, por exemplo, emprega a expressão "amplo contraditório" para indicar esse conjunto, adequada ao nosso ver. Interessante também, a posição de Nelson Nery Júnior ${ }^{46}$, ao dizer no âmbito do processo civil:

"Por contraditório deve entender-se, de um lado, a necessidade de dar-se conhecimento da existência da ação e de todos os atos do processo às partes, e de outro, a possibilidade de as partes reagirem aos atos que lhe sejam

39 Ver LFPA, art. $2^{\circ}$, parágrafo único, $\mathrm{X}$

40 Ver art. 46 . $C f$. tb. $C F$, art. $5^{\circ}, \mathrm{X}$.

41 Cf. Odete Medauar, op. cit., p. 106; e Héctor Jorge Escola, op. cit., p. 145; Dinorá Adelaide Museti Grotti, op. cit., p. 38.

42 Ver STF, AGRAG n ${ }^{\circ}$ 142847-SP, Rel. Min. Marco Aurélio, Segunda Turma, unânime pelo não provimento, julgado em 01.12.92, publicado no DJ de 05.02.93; e STJ, MS n $3889-\mathrm{DF}$, Rel. Min. Gilson Dipp, Terceira Seção, unânime pelo indeferimento, julgado em 13.10.99, publicado no DJ de 16.11.99.

43 Ver LFPA arts. 29, caput; 38, caput, 39, caput, e parágrafo único; e 41.

44 Cf. Carlos Mário da Silva Velloso, op. cit., p. 229.

45 Curso..., cit., pp. 410-411.

46 Op. cit., pp. 122-123. 
desfavoráveis. Os contendores têm direito de deduzir suas pretensões e defesas, realizarem as provas que requereram para demonstrar a existência de seu direito, em suma, direito de serem ouvidos paritariamente no processo em todos os seus termos."

"Ampla defesa" consiste no direito constitucional do administrado de contestar, em favor de si próprio, condutas, imputações, fatos, argumentos ou interpretações que possam atingir a sua esfera jurídica individual, devendo ainda ser assegurados ainda os meios e recursos indispensáveis para o seu exercício ${ }^{47}$.

Embora fortemente relacionados, é possível fazer um corte cuidadoso entre esses dois preceitos, no sentido de visualizar o contraditório como pressuposto material necessário para a ampla defesa. Sem que o administrado acusado ou litigante conheça a existência do processo ou mesmo a iminência da medida que o atingirá, defesa alguma é efetivamente viável.

A ampla defesa deve ser conseqüência do contraditório, quando o administrado não se resigna do que conheceu. Se, por injunção da própria Administração, o contraditório é inexistente, tardio, efêmero ou insuficiente, fica o processo administrativo maculado de vício atentatório à própria Lei Maior ${ }^{48}$. Não há, nestas situações, o amplo contraditório.

Também a LFPA, em diversos dispositivos, concedeu maior densidade a esse direito constitucional fundamental. Há seu reconhecimento expresso, no art. $2^{\circ}$, caput, desse diploma legal.

\subsubsection{Direitos à defesa prévia e à produção de provas}

Muitas vezes, pode haver tensão entre a ampla defesa e as características da atividade administrativa. A defesa prévia, naturalmente ensejada pelo contraditório pode ser vista como um empecilho ao interesse público, nos casos de envolvendo risco à vida e à segurança da população, e nas situações onde ela é materialmente impossível, no caso das multas de trânsito ${ }^{49}$.

Mas a defesa prévia deve ser a regra. A LFPA ${ }^{50}$ prescreve como direito do administrado perante a Administração, formular alegações e apresentar documentos antes da decisão, que devem ser necessariamente objeto de, consideração pelo órgão competente. Confere a LFPA $^{51}$ poder para que o órgão competente rejeite provas ilícitas, impertinentes, desnecessárias ou protelatórias.

Quanto o direito à produção de provas, em diversos pontos a LFPA o confere aos administrados. Assegura ao interessado o direito de requerer atuações probatórias

47 Odete Medauar, op. cit., 111-112.

48 Cf. Lúcia Valle Figueiredo, Curso..., cit., p. 411.

49 Cf. Odete Medauar, op. cit., p. 116.

so Arts. $3^{\circ}$, III; e 38, $\S 1^{\circ}$.

51 Arts. 30; e 38, $\$ 2^{\circ}$. Cf. tb. CF, art. $5^{\circ}$, LVI. Ver Lúcia Valle Figueiredo, Curso..., cit., pp. 414-415. 
ao lado da ação de ofício da Administração, devendo o órgão competente fixar os dados necessários para a tomada da decisão e os meios menos onerosos quando exigido ato do interessado ${ }^{52}$ garante a obtenção de ofício dos documentos necessários para a comprovação de fatos alegados nos autos, constantes nos arquivos da própria Administração ${ }^{53}$; determina a intimação dos interessados de prova ou diligência ordenada, com antecedência mínima de três dias úteis, com a menção da data, hora e local de sua realização ${ }^{54}$; faculta ao interessado manifestar-se, no prazo máximo de dez dias (se outro não tiver sido fixado em lei), após o encerramento da instrução ${ }^{55}$.

\subsubsection{Direito à defesa técnica}

A LFPA $^{56}$ assegura o direito ao administrado de se fazer assistir de profissional habilitado para a defesa de seus interesses junto à Administração, salvo se obrigatória a representação por força de lei.

Quando a matéria do processo administrativo implicar em sanção, ou seja, colocar o administrado na posição de acusado, melhor se concilia com os preceitos constitucionais a obrigatoriedade da defesa técnica, cabendo inclusive a nomeação de defensor dativo se ausente ${ }^{57}$.

\subsubsection{Direitos à revisibilidade e à motivação}

Assegurado pela própria Constituição Federal ${ }^{58}$, a LFPA $^{59}$ consagra o direito à recurso, decorrência sem dúvida do princípio da ampla defesa. Como as questões a ele relacionadas - bastante instigadoras por sinal - merecem análise mais detida e não guardam direta relação com o tema em curso, delas não trataremos aqui ${ }^{60}$.

Outro direito expressamente alcançado com a LFPA ${ }^{61}$, é a cognição pelo administrado dos fundamentos de fato e de direito que justificam a decisão administrativa, recepcionando longo labor doutrinário para reconhecê-lo no regime jurídico-administrativo ${ }^{62}$. Sem motivação, o direito ao recurso administrativo é inócuo, bem como qualquer medida judicial de controle da administração ${ }^{63}$.

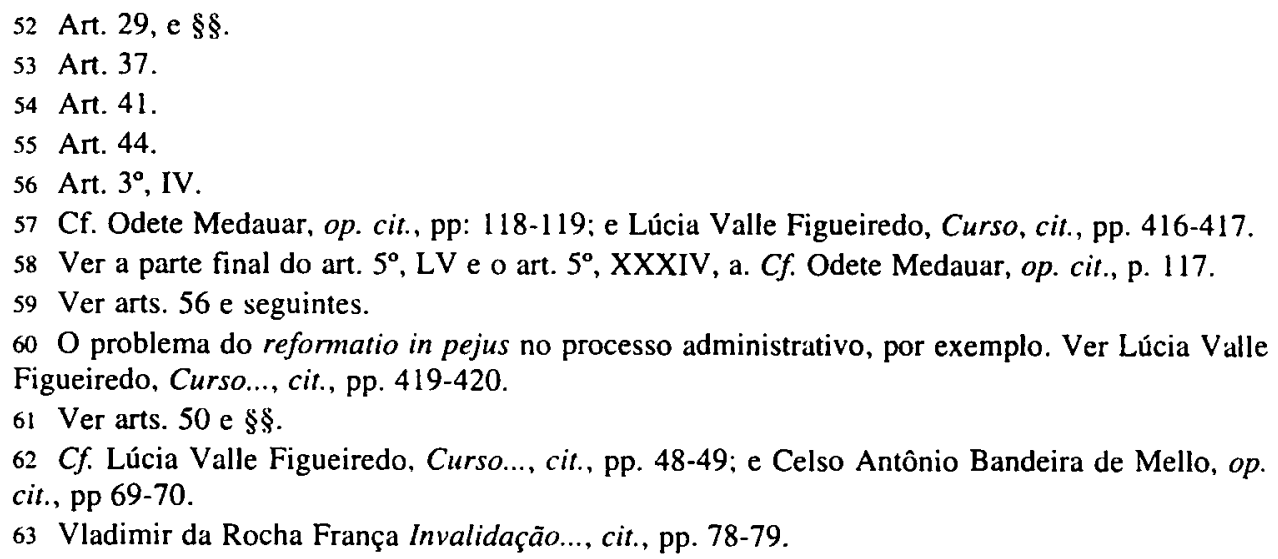


A motivação, segundo a LFPA ${ }^{64}$, é dever da Administração, que deve emitir explicitamente decisão nos processos administrativos, solicitações e reclamações, observada as regras de competência, dentro de até trinta dias úteis após a conclusão da instrução (caso não haja prorrogação também motivada por igual período).

\section{4 - Sobre a Exigibilidade do Contraditório na Invalidação Administrativa}

\section{1 - Invalidação, revogação e convalidação}

Determina-se a existência material do ato administrativo pela sua forma revestimento exterior - e conteúdo - a prescrição do nascimento, mudança, reconhecimento ou término de uma relação jurídica administrativa; isso, independentemente de sua conciliação ou não com o regime jurídico-administrativo ${ }^{65}$. É exigido do conteúdo do ato natureza normativa e seu acatamento pelos administrados ${ }^{66}$. Sem esses elementos, o provimento administrativo não existe como ato nem como fato.

A validade consiste no vínculo que se estabelece entre a norma jurídica e o ordenamento jurídico, "por terem sido obedecidas as condições formais e materiais de sua produção e consequente integração no sistema" ${ }^{67}$.

E como bem ensina Tércio Sampaio Ferraz Júnior ${ }^{68}$ :

"A validade da norma não é uma qualidade intrínseca, isto é, normas não são válidas em si: dependem do contexto, isto é, dependem da relação da norma com as demais normas do contexto. O contexto, como um todo, tem que ser reconhecido como uma relação ou conjunto de relações globais de autoridade. Tecnicamente diríamos então, que a validade de uma norma depende do ordenamento no qual está inserida".

Portanto, para que haja o ingresso formal do ato administrativo no regime jurídico-administrativo, é preciso configurar sua existência, ou seja, identificar a forma e o conteúdo. Mas a existência pressupõe o esgotamento de todas as fases necessárias para a formação do ato ${ }^{69}$.

O ato administrativo presume-se válido em virtude da presunção de legitimidade de que gozam - atributo concedido pelo regime jurídico-administrativo quando

64 Ver arts. 48 e 49.

65 Cf. Vladimir da Rocha França, "Fundamentos da Discricionariedade Administrativa", in: Revista dos Tribunais, Vol. 768, p. 61; e idem, Invalidação..., cit., p. 117.

66 Cf. Carlos Ari Sundfeld, Ato Administrativo Inválido, São Paulo, Malheiros, 1990, pp. 15-22;

e Tércio Sampaio Ferraz Júnior, Introdução ao Estudo do Direito, 2* ed., São Paulo, Atlas, 1994,

p. 184.

67 Tércio Sampaio Ferraz Júnior, op. cit., p. 205.

68 Op. cit., p. 174.

69 Idem, ibidem, p. 196. 
ingressam formalmente no sistema de direito positivo ${ }^{70}$. Todo o ato administrativo é idôneo para produzir os seus efeitos jurídicos, até a comprovação definitiva de sua invalidade, podendo haver a sustação provisória dos mesmos enquanto pendente a aferição de sua coerência e afinidade para com o sistema de direito positivo ${ }^{71}$.

A estabilidade da validade do ato administrativo dependerá de sua efetiva subordinação aos cânones do sistema de direito positivo ${ }^{72}$. Para o ato jurídico ser materialmente válido no regime jurídico-administrativo, é preciso haver competência, conteúdo lícito, obediência à forma prescrita em lei (quando esta for expressa nesse sentido), bem como, ser precedido de motivo juridicamente aceito e, orientação para a tutela do interesse público. Estes dois últimos elementos são essenciais para a diferenciação do ato jurídico administrativo para o ato jurídico privado ( $c f$. art. 81 do Código Civil). Neste, tais requisitos são inexistentes, pois o motivo e a finalidade do ato jurídico no direito privado são determinados pelas livres e lícitas opções dos particulares, haja vista a força e a presença do princípio da autonomia da vontade ${ }^{73}$.

A perda da validade do ato administrativo pode se dar através da invalidação ou da revogação. É preciso outro ato administrativo, ou norma de hierarquia superior, para se retirar a validade do ato administrativo ${ }^{74}$.

Quando o ato administrativo é atentatório aos princípios e regras do ordenamento jurídico, sua permanência no regime jurídico-administrativo torna-se passível de ser contestada e, por conseguinte, fica o ato sujeito à invalidação ${ }^{75}$.

$\mathrm{O}$ ato administrativo é juridicamente eficaz quando, juridicizando o fato, possui idoneidade para a determinar, formar e regular as situações jurídicas individuais que são objeto do regime jurídico-administrativo. Tal aptidão decorre da inexistência de entraves para que o ato produza seus efeitos típicos (termo inicial, condição suspensiva ou ato controlador de outra autoridade), como bem leciona Celso Antônio Bandeira de Mello $^{76}$. Mas dentro de um sentido lógico-formal, já que do ponto-devista sociológico, há eficácia quando há a conformação da conduta ao preceito normativo ${ }^{77}$

70 Cf. Celso Antônio Bandeira de Mello, op. cit., p. 297. Ver STJ, RESP n 41519-RJ, Rel. Min. Luiz Vicente Cernicchiaro, Sexta Turma, unânime pelo não conhecimento, julgado em 01.03.94, publicado no DJ de 28.03.94; e TJDF, Ap. Civ. n 3617.95, Rel. Des. Getúlio Moraes de Oliveira. Segunda Turma Cível, unânime pelo desprovimento, julgado em 26.08.96, publicado no DJ de 20.11.96.

71 Cf. Hely Lopes Meirelles, Direito Administrativo Brasileiro, 20 ed., São Paulo, Malheiros, 1995, p. 141; e Tércio Sampaio Ferraz Júnior, op. cit., p. 174.

72 Cf. Vladimir da Rocha França, Invalidação..., cit., p. 117: e Carlos Ari Sundfeld, Ato.., cit., p. 23.

73 Cf. Caio Tácito, "Ato e Fato Administrativo", in: Temas de Direito Público (Estudos e Pareceres), $1^{\circ}$ Vol., Rio de Janeiro, Forense, 1997, pp. 299-300.

74 Cf. Lúcia Valle Figueiredo, Curso..., cit., pp. 225-226.

75 Vladimir da Rocha França, Invalidação..., cit., p. 119.

76 Op. cit., p. 273.

77 Cf. Tércio Sampaio Ferraz Júnior, op. cit., pp. 200-202. 
A perfeição do ato administrativo não prescinde da eficácia jurídica, uma vez que esta é pressuposto para a geração de direitos subjetivos e para criar situações juridicas subjetivas ${ }^{78}$. Perfeito o ato administrativo, ele se torna inatingível pela lei, no que concerne aos direitos subjetivos por ele gerados para os administrados que alcançarem o padrão de direito adquirido, por força da Constituição Federal vigente.

Para que o ato administrativo possa ser considerado um ato jurídico perfeito, é preciso que sua eficácia jurídica seja suficiente para permitir o regular e válido ingresso de um direito subjetivo na esfera jurídica do administrado ou permitir a consolidação válida de uma dada situação jurídica (ato consumado). Há respeitada doutrina $^{79}$, que identifica a perfeição do ato administrativo quando encerrado seu processo de formação. Esta posição, a nosso ver, não está conciliada com nosso direito positivos ${ }^{80}$. Ver a Lei de Introdução ao Código Civil, art. $6^{\circ}$ e 0 art. $5^{\circ}$, XXXVI, da Constituição Federal em vigor.

$O$ ato administrativo não deve ser confundido com os atos materiais inerentes à sua execução, e nem estes devem enquadrar-se nessa categoria ${ }^{81}$. A ação material da administração é fato juŕdico-administrativo, juridicizado pela norma jurídica denominada ato jurídico-administrativo. $O$ excesso ou insuficiência na execução do ato administrativo não induz a sua invalidade, mas sim a responsabilização do Estado pelos danos oriundos da falha da Administração nesse sentido. Nem sempre após um ato administrativo válido, segue-se uma conduta lícita.

A invalidação não se confunde com a revogação. $\mathrm{Na}$ revogação, há o desfazimento total ou parcial do ato administrativo, pela própria Administração, por motivos de conveniência e oportunidade ${ }^{82}$. Embora válido e eficaz ${ }^{83}$, a manutenção do ato administrativo se torna politicamente insustentável, em face da sensível alteração que as circunstâncias do caso concreto sofreram, transformando o que, no momento da sua expedição, era conveniente e oportuno ${ }^{84}$. Revogado o ato administrativo, os efeitos já produzidos são respeitados, cessando-se os efeitos futuros ${ }^{85}$.

Embora também implique na retirada do ato administrativo, diferenciam-se quanto ao fundamento da expulsão do mesmo do sistema ${ }^{86}$. A revogação tem um

78 Cf. Hely Lopes Meirelles, op. cit., pp. 142-143.

79 Cf. Celso Antônio Bandeira de Mello, op. cit., pp. 272-273; Lúcia Valle Figueiredo, Curso..., pp. 155-157.

80 Ver CF, art. $5^{\circ}, \mathrm{XXXVI}$ : e Lei de Introdução ao Código Civil, art. $6^{\circ}$.

81 Cf. Vladimir da Rocha França, Invalidaçāo..., cit., p. 119.

82 Miguel Seabra Fagundes, "Revogação e Anulamento do Ato Administrativo", in: Revista de Direito Administrativo - Seleção Histórica, 1991, p. 57.

83 Ou válido, eficaz e perfeito, caso se trate de revogação parcial do ato administrativo, já que houve a geração de direitos subjetivos.

84 Vladimir da Rocha França Invalidação..., cit., p. 119.

85 Recorrendo-se mais uma vez a Tércio Sampaio Ferraz Júnior (op. cit., p. 203), a eficácia jurídica não se revoga, anula-se.

86 Publicado no DJ de 25.10.91. Cf. Caio Tácito, "Controle Judicial da Administração Pública", in: Temas de Direito Público (Estudos e Pareceres), $1^{\circ}$ Vol., Rio de Janeiro, Renovar, 1997, p. 1.002 . 
regime jurídico que lhe é peculiar, não permitindo, ao nosso ver, enquadrá-lo como uma meio de restauraçāo da juridicidade administrativa, mas sim como um modo de melhor adequação político-social do regime jurídico-administrativo às mudanças da realidade social.

Enquanto o emprego da invalidação busca diretamente a manutenção da integridade do regime jurídico-administrativo, o emprego da revogação concede nova orientação para o regime jurídico-administrativo no caso concreto, em virtude da mudança do contexto político e social, observados os cânones jurídicos.

A revogação do ato administrativo não deixa de ter natureza discricionária, mas o emprego dessa prerrogativa não se faz sem o respeito aos limites impostos pelo regime jurídico-administrativo ${ }^{87}$. As situações jurídicas constituídas sob o regime do ato revogado devem ser mantidas.

Ao contrário da revogação, que é exclusiva da Administração, a invalidação pode se dar por via judicial ou por via administrativa.

O Supremo Tribunal Federal, ao editar as Súmulas n 346 e $n^{\circ} 473$, reconheceu à Administração a faculdade de anular os seus próprios atos quando constata vícios que o tornem ilegais. E a LFPA agora dispõe, em seu art. 53:

“Art. 53. A administração deve anular seus próprios atos quando eivados de vício de legalidade, e pode revogá-los por motivo de conveniência ou oportunidade, respeitados os direitos adquiridos".

Há posicionamento doutrinário, anterior á LFPA, entendendo que a invalidação pela Administração possui natureza discricionária ${ }^{88}$

Assim não entende Carlos Ari Sundfeld ${ }^{89}$, segundo o qual "a Administração tem o dever de restaurar a legalidade ferida, não possuindo qualquer poder discricionário para optar por não restaurá-la". Haveria, para ele, discricionariedade apenas quanto à escolha a forma: invalidação e convalidação ${ }^{90}$.

Celso Antônio Bandeira de Mello ${ }^{91}$ e Weida Zancaner ${ }^{92}$ (op. cit., pp. 55-59) entendem que não há discrição para a escolha do modo de recomposição da juridicidade (excetuando-se o caso do ato discricionário com vício de competência). Deve

87 Cf. José Frederico Marques, "A Revogaçāo dos Atos Administrativos", in: Revista de Direito Administrativo - Seleção Histórica, 1991, pp. 299-300; Celso Antônio Bandeira de Mello, op. cit., pp. 327-328: e Hely Lopes Meirelles, op. cit., pp. 185-186. Sobre a exigibilidade do devido processo legal administrativo no exercício da revogação, ver STJ, MS n 5431-DF, Rel. Min. Milton Luiz Pereira, Primeira Turma, maioria pela concessão parcial da segurança, julgado em 23.09.98, publicado no DJ de 17.05.99.

88 Miguel Seabra Fagundes, op. cit., pp. 61-62. Mesmo assim, tal discricionariedade não existiria para os órgãos judiciários ( $c f$. José Frederico Marques, op. cit., p. 301 ).

89 Ato..., cit., pp. 84-85. Cf. Celso Antônio Bandeira de Mello, op. cit., p. 341; e Weida Zancaner, Da Convalidação e da Invalidaçāo dos Atos Administrativos, São Paulo, Malheiros, 1993, p. 47.

90 Cf. LFPA, art. 55.

91 Op. cit., pp. 339-341.

92 Op. cit., pp. 55-59. 
a administração pública convalidar o ato administrativo sempre que possível, em obediência aos princípios da boa fé e da segurança jurídica. Se o ato administrativo não pode ser substituído por outro que supra os seus defeitos, há então o dever de invalidar. Caso não haja quebra do interesse público ou lesão a direito de terceiro, e sendo a falha sanável, a saída deve ser a convalidação do ato administrativo.

Convalidação deve ser entendida como a repetição do ato administrativo viciado quando pode ser validamente aceito no regime jurídico administrativo com a correção do defeito, sem maiores prejuízos para o sistema, com efeitos retroativos ${ }^{93}$. Enquanto na invalidação, há a desconstituição dos efeitos produzidos na passado, procurandose repor a situação anterior ao surgimento do ato viciado, na convalidação, elimina-se o ato viciado pela sua substituição por outro, que "herda seus efeitos, tornando-os como seus e fazendo-os sobreviver" 94 .

A possibilidade da convalidação do ato administrativo como modo de restauração da juridicidade não tinha aceitação pacífica na doutrina. Hely Lopes Meirelles rejeitava-a "pela impossibilidade de preponderar o interesse privado sobre o público e não ser admissível a manutenção de atos ilegais, ainda que assim o desejem as partes, porque a isto se opõe a exigência da legalidade administrativa" 95 .

$\mathrm{O}$ regime jurídico-administrativo acolheu a convalidação. Não raras vezes, a invalidação completa do ato provoca muito mais transtornos para as relações entre Administração e administrados, do que o seu saneamento. A convalidação não deixa de ser um modo de tutela juridicamente legítimo do próprio interesse público ${ }^{96}$. Mas o seu emprego não deve ser indiscriminado. Aliás, o art. 55 da LFPA estabelece o seguinte:

“Art. 55. Em decisão na qual se evidencie não acarretarem lesão a interesse público nem prejuízo a terceiros os atos que apresentarem defeitos sanáveis poderão ser convalidados pela própria administração".

Por conseguinte, constatado o vício, o ato administrativo pode ser invalidável ou convalidável ${ }^{97}$. Se há vício, e este é sanável sem prejuízo ao interesse público ou a direito subjetivo de terceiro, deve haver a convalidação. Se o vício não pode ser reparado, deve a Administração invalidá-lo.

Mas o ato convalidável não deve ser confundido com o "ato anulável" do direito privado. Não vemos espaço para as categorias "atos anuláveis" e "atos inexistentes" ${ }^{98}$. Se, por qualquer razão, o ato que pode ser convalidado é submetido à

93 Cf. Celso Antônio Bandeira de Mello, op. cit., p. 234; Weida Zancaner, op. cit., p. 56; e Carlos Ari Sundfeld, op. cit., pp. 50-53.

94 Carlos Ari Sundfeld, op. cit., p. 51.

95 Op. cit., pp. 156-157 (grifo no original).

96 Weida Zancaner, op. cit., p. 59.

97 Cf. Vladimir da Rocha França, Invalidação..., cit.. p. 123.

98 Sobre a questão a existência dos "atos inexistentes", ver Caio Tácito, "A Teoria da Inexistência do Ato Administrativo", in: Temas de Direito Público (Estudos e Pareceres), $1^{\circ}$ Vol., Rio de Janeiro, Renovar, 1997, p. 313: Celso Antônio Bandeira de Mello, op. cit., p. 341; e Weida Zancaner, op. cit., 97-98. 
invalidação judicial, o ato é submetido ao mesmo regime do ato invalidável, no direito positivo brasileiro.

Outro aspecto também impede a inserção da teoria da nulidade relativa no direito administrativo positivo. A nulidade relativa ocorre quando há exclusivo interesse dos particulares, onde a manutenção do ato fica à discrição das partes envolvidas ${ }^{99}$. A análise dos atos administrativos envolve necessariamente o interesse público, que não pode ficar submetido ao capricho do administrado. ${ }^{100}$ Constatado o vício e prejudicada a convalidação, a iniciativa para a provocação do processo de invalidação judicial) é amplo, seja qual for sua natureza.

O que se chama de "ato inexistente" é, na verdade, um delito cometido por um agente da Administração, ou seja, um fato jurídico, e não um ato administrativo, pois não chega a ingressar no sistema como norma ${ }^{101}$. Somente é relevante para o direito administrativo no que concerne à responsabilização do Estado pelos danos causados aos administrados e ao exercício do poder disciplinar da Administração.

Sem a manifestação normativa competente, o ato administrativo portador de vício permanece no sistema. Embora o ato implique em atentado à ordem jurídica, a restauração da juridicidade ferida depende da expedição de outro ato administrativo. A invalidação e a convalidação são meios estabelecidos pelo próprio regime jurídico-administrativo para a eliminação material do vício, preservando a segurança jurídica e a integridade dos princípios que regem essa parcela do sistema de direito positivo. Se assim não fosse, bastaria confiarmos no administrador, e o controle da Administração, por conseguinte, seria algo inútil.

Se a Administração não convalida, o ato se torna passível de invalidação pelo Poder Judiciário, se, é claro, este for provocado para fazê-lo. O mesmo serve para a hipótese da administração se abster de invalidar quando deveria tê-lo feito ${ }^{102}$.

\section{2 - Limites à invalidação administrativa}

A invalidação tem efeitos $e x-\operatorname{tun} c^{103}$, retirando o ato administrativo do sistema ou desconstituindo as relações jurídicas que foram geradas durante sua permanência no mesmo, conforme a eficácia jurídica do ato. A revogação, por sua vez, tem efeitos ex-munc, suprimindo o ato ou seus efeitos, respeitando as efeitos já transcorridos ${ }^{104}$. Quanto ao modo de incidência da invalidação, há as seguintes possibilidades ${ }^{105}$ :

99 Cf. Orlando Gomes, Introdução ao Direito Civil, 1* ed., Rio de Janeiro, Forense, 1988, pp. 491-492.

100 Cf. Hely Lopes Meirelles, op. cit., p. 189.

101 Cf. Tércio Sampaio Ferraz Júnior, op. cit., pp. 215-217; e Celso Antônio Bandeira de Mello, op. cit., p. 341.

102 Cf. Vladimir da Rocha França, Invalidaçāo..., cit., p. 123.

103 Celso Antônio Bandeira de Mello, op. cit., pp. 331-332.

104 Idem, ibidem, p. 326.

105 Recorde o leitor que entendemos os atos administrativos como normas individuais e concretas. 
a) Se $O$ ato administrativo é ineficaz, a invalidação terá incidência direta no próprio ato, retirando-o do regime jurídico-administrativo e, por conseguinte, eliminando a possibilidade de implementação dos efeitos que adviriam do ato viciado ${ }^{106}$;

b) Por fim, se o ato administrativo é eficaz e foi concretizado, a invalidação somente incidirá nos efeitos que ainda remanescem ${ }^{107}$.

Mas há limites que devem ser observados para o exercício da invalidação administrativa.

O art. 54, caput, da LFPA fixa prazo de natureza decadencial - cinco anos contados da prática do ato - para que a Administração exerça sua prerrogativa de invalidação em atos administrativos que acarretarem efeitos favoráveis a administrados de boa fé e, a nosso ver, caso não possa haver a convalidação.

Determina ainda a LFPA ${ }^{108}$ que qualquer medida de autoridade administrativa orientada à impugnação à validade do ato tem peso de invalidação.

Acolhe expressamente o regime jurídico-administrativo, lição de Weida Zancaner ${ }^{109}$, que aponta a subordinação da prerrogativa administrativa de invalidar à decadência, ou seja, há a sua perda caso não seja exercida dentro do prazo legalmente estabelecido. Havendo a decadência, perece toda e qualquer medida judicial $e$ administrativa que a Administração possa intentar para invalidar o ato, restando tão-somente a possibilidade de punição do servidor que lhe deu causa ${ }^{110}$.

E como bem lembra Lúcia Valle Figueiredo"11:

“(...) a invalidação tornar-se-á impossível, por ilegítima, quando se encontre a Administração Pública diante do exaurimento atual de sua competência para agir."

Se a Administração decai dessa prerrogativa, pode o administrado lesado, ou seja, o não beneficiado, recorrer às vias judiciais para pleitear a invalidação do ato ou a responsabilização do Estado pelos danos causados. Entendemos que o prazo prescricional para a invalidação judicial de ato administrativo é o de cinco anos,

106 "(...) em Direito, ato administrativo significa uma fonte, uma matriz de efeitos jurídicos. Esta fonte que é o ato não se confunde com os efeitos dele nascidos. São coisas distintas o produtor (ato) e o produzido (efeitos). Quando se ataca um ato ineficaz, seja ele ato abstrato ou ato concreto, os efeitos previstos ainda não eclodiram (...). Elimina-se aquela fonte da qual dependia o surgimento de efeitos" (idem, ibidem, p. 331).

107 Mas uma vez, a lição de Celso Antônio Bandeira de Mello (op. cit., p. 332; grifo no original) é indispensável: "Nestes casos, a invalidação quer eliminar retroativamente o que ainda existe: a relação jurídica. Do ato não há mais cuidar, pois desapareceu com sua aplicação concreta, isto é, a única".

108 Art. 54, $\S 2^{\circ}$.

109 Op. cit., pp. 76-77.

110 Cf. Yussef Said Cahali, "Decadência”, in: Enciclopédia Saraiva do Direito, Vol. 22, Sāo Paulo, Saraiva, 1979, p. 365; e Orlando Gomes, op. cit., p. 520.

111 Curso..., cit., p. 227. 
como prescreve o Dec. 20.910/32, art. $1^{\circ}$. Se o ato implicar em lesão à direito real do administrado, considerável parte da doutrina e a jurisprudência entendem que a prescrição ocorre consoante o estipulado no art. 177 do Código Civil (dez anos entre presentes, e quinze, entre ausentes), em respeito à instituição jurídica da proprieda$\mathrm{de}^{112}$.

E se, decorridos cinco anos, havendo comprovação de má fé, a Administração não exerce sua prerrogativa e não há provocação do Poder Judiciário? Pode a Administração invalidar o ato a qualquer tempo? A segurança jurídica é um dos princípios basilares de qualquer sistema de direito positivo ${ }^{113}$. A saída mais conciliada com tal princípio é, a nosso ver, a de permitir a invalidação administrativa do ato, não desconstituindo os efeitos pretéritos $\mathrm{e}$, indenizando os terceiros de boa fé que ingressaram em situações provocadas pelo ato viciado, após o decurso do lapso temporal citado, pelos danos causados pela restauração da juridicidade. Como bem determina a LFPA ${ }^{114}$ deve a Administração interpretar a norma administrativa da forma que melhor garanta "o fim público a que se dirige".

Quando o ato administrativo portador de vício é invalidado antes que o administrado ingresse na relação jurídica por ele constituída, ou, se o ato é ineficaz, não há nenhuma consequiência de ordem patrimonial, uma vez que não houve dano concreto $^{115}$.

Se o administrado tiver atuado em função do ato portador de vício, e a invalidação ocorre após a efetivação da relação jurídica, a comprovação da boa fé e de sua não concorrência para o vício do ato, assegura ao administrado a preservação dos efeitos patrimoniais passados, ou indenização, na pendência de prestação da Administração ${ }^{116}$. Do contrário, a desconsideração total dos efeitos do ato invalidado, neste caso, implicaria num paradoxal enriquecimento sem causa, bem como em violação dos princípios da isonomia, moralidade e da proporcionalidade. Até mesmo a invalidação judicial deve observar estes limites.

A não proteção dos administrados de boa fé na invalidação do ato administrativo, tanto a administrativa como a judicial, quebra a isonomia por onerar excessivamente o indivíduo em favor da coletividade, produzindo uma equação perversa para quem procurou se sujeitar ao direito positivo. Quebra a moralidade, por ignorar a própria boa fé do administrado, desconsiderando a sua condição de cidadão. E, por fim, quebra a proporcionalidade, por representar um excesso no exercício da prerrogativa de invalidar, pois o interesse público não pode ser concretizado com o total esmagamento do interesse particular, devendo a administração buscar meios mais adequados e menos danosos aos direitos dos administrados. Recorde-se a prescrição da LFPA $^{117}$, tornando critério obrigatório à Administração a "adequação entre meios e

112 Cf. Hely Lopes Meirelles, op. cit., p. 626.

113 Cf. LFPA, art. $2^{\circ}$, caput.

114 Art. $2^{\circ}$, parágrafo único. XIII.

115 Celso Antônio Bandeira de Mello,, p. 343.

116 Idem.

117 Art. $2^{\circ} \S 2^{\circ}$, VI. 
fins, vedada a imposição de obrigações restrições e sanções em medida superior àquelas estritamente necessárias ao atendimento do interesse público". Deve ser o administrado punido e constrangido porque obedeceu à obrigação de lealdade, urbanidade e boa fé, prescrita na LFPA ${ }^{118}$ ?

No caso, não estará havendo convalidação dos efeitos de um ato portador de vício, mas sim a manutenção da juridicidade dos efeitos pretéritos e o impedimento de efeitos futuros, em prol do interesse público, pela invalidação. Ao se recompor a esfera jurídica do administrado de boa fé com uma indenização, reconhece o Estado que seu interesse era juridicamente legítimo, mas por força dos princípios da prevalência do interesse público sobre o interesse privado e da indisponibilidade do interesse público, sua inteira manutenção implicaria em quebra do regime jurídico-administrativo.

Se a contraprestação do Poder Público já foi realizada e incurso o administrado em boa fé, deve a Administração preservar os efeitos já transcorridos, não os desconstituindo, a não ser que sua manutenção implique em forte gravame ao interesse público. É um mandamento decorrente do princípio da segurança jurídica.

\subsection{Contraditório e a prevalência do interesse público sobre o interesse privado}

Recordemos o enunciado do art. $5^{\circ}$, LV, da Constituição Federal:

"Art. 5०. (...)

(...)

LV - aos litigantes, em processo judicial ou administrativo, e aos acusados em geral são assegurados o contraditório e ampla defesa, com os meios e recursos a ele inerentes."

Quando a invalidação administrativa atinge ato administrativo que gerou efeito favorável a administrado ou; quando ineficaz, torna previsível sua eclosão, há uma situação potencial de litigância, a nosso ver, entre a Administração e o administrado. Não se pode negar que, nessa matéria, há uma contraposição entre o interesse individual do administrado - $o$ acesso ao benefício auferido através da própria ação da Administração - e o interesse público - a integridade da ordem jurídica - a ser tutelado pelo Poder Público.

Mesmo quando o administrado se portou com má fé, concorrendo para o vício, a invalidação administrativa não constitui sanção por ato ilícito do cidadão, mas, tão-somente a restauração da juridicidade ferida através da retirada do ato invalidável do sistema em razão de conduta ilegal, ainda que essa medida impeça a eclosão ou desconstitua os efeitos favoráveis dele decorrentes. Deve ser ressaltado que o administrado de má fé pode ser submetido a sanções de ordem civil, administrativa e penal, pela conduta ilícita atentatória à administração pública. Portanto, na invali-

118 Ver art. $4^{\circ}$, II. 
dação administrativa o administrado não figura como acusado, ainda que sua má fé possa ser argüida pela Administração no exercício dessa prerrogativa, como elemento concorrente para o vício surpreendido no ato.

A invalidação administrativa representa a processualidade que deve preceder 0 ato administrativo que invalida o ato portador de vício no regime jurídico administrativo. Caso se trate de ato administrativo que possa ensejar ou que tenha gerado efeito favorável ao administrado, obrigam a Constituição Federal e a LFPA a comunicação prévia do mesmo sobre a iminência de ato administrativo de invalidação e, por conseguinte, a instauração de um processo administrativo. Aqui, a invalidação administrativa assume para sua regularidade a natureza de processo, pois determina a participação dos administrados que serão atingidos pelo ato final. Como bem ensina Dinorá Adelaide Museti Grotti ${ }^{119}$.

"(...) não pode a Administração suprimir direitos ou desconstituir situações, sem que ouça o administrado preliminarmente".

A LFPA estabelece em seu art. $9^{\circ}$, II, que são legitimados como interessados no processo administrativo " aqueles que, sem terem iniciado o processo, tem direitos ou interesses que possam se afetados pela decisão a ser adotada" ${ }^{20}$. Embora o ato administrativo de invalidação somente possa ser expedido pela Administração, o processo administrativo que, no caso, deve precedê-lo, pode ser iniciado de ofício ou a pedido de outro administrado ${ }^{12 !}$.

Em complemento, lembremos mais uma vez que a LFPA estatui o direito do administrado de ter ciência da tramitação dos processos em que tenha condição de interessado ${ }^{122}$, bem como a garantia do direito à comunicação nas situações de litígio ${ }^{123}$.

Entretanto, há entendimento jurisprudencial em favor da não exigibilidade de processo administrativo prévio para a expedição de ato administrativo de invalidação, por se tratar do exercício de uma prerrogativa da administração, podendo caber a responsabilidade do Estado pelas perdas e danos causados pela medida ${ }^{124}$. Mas longe

119 Op. cit., p. 37 (grifo no original). Cf. Mônica Martins Toscano, op. cit., p. 219.

120 Cf. Elio Fazzalari, op. cit., p. 820; e Héctor Jorge Escola, op. cit., pp. 172-176.

121 Ver CF, art. $5^{\circ}$, XXXIV, a; e LFPA, art. $5^{\circ}$ Cf. José Cretella Júnior, op. cit., p. 45.

122 Ver art. $3^{\circ}$, II.

123 Ver art. $2^{\circ}$, parágrafo único, $X$.

124 Ver STF, RE n 185255-AL, Rel. Min. Sydney Sanches, Primeira Turma, unânime pelo não provimento, julgado em 01.04.1997, publicado no DJ de 19.09.97; STJ, MS n ${ }^{\circ}$ 5611-DF, Rel. Min. Milton Luiz Pereira, Primeira Turma, julgado em 09.09.98, publicado no DJ de 29.03.99; STJ, ROMS n 10406-SC, Rel. Min. Edson Vidigal, Quinta Turma, unânime pelo não provimento, julgado em 09.11.99, publicado no DJ de 13.12.99; e STJ, ROMS $n^{\circ}$ 10474-ES, Rel. Min. Gilson Dipp, Quinta Turma, unânime pelo não provimento, julgado em 25.05 .99 , publicado no DJ de 25.10.99. 
de obter unanimidade, reconhecendo outros julgados o caráter indispensável do contraditório para o válido exercício dessa prerrogativa administrativa ${ }^{125}$.

Assim nos posicionamos quanto à matéria.

Não conseguimos visualizar qualquer argumento robusto o suficiente para afastar totalmente o contraditório quando a Administração está prestes a exercer sua prerrogativa de restaurar a juridicidade violada pela retirada do ato portador de vício.

De modo algum, a exigência do contraditório é incompatível com a invalidação administrativa. Embora, seja um dever-poder da Administração, é incompreensivel que se negue a possibilidade do regime jurídico-administrativo estabelecer uma garantia para o administrado de boafé. Se a mera concessão legal de uma prerrogativa para a Administração dispensasse a observância do devido processo legal administrativo, que razão haveria para o enunciado do art. $5^{\circ}$, inc. LV, da Lei Maior? O poder disciplinar, por exemplo, pelo simples fato de ser inegavelmente reconhecido à Administração em relação aos seus agentes poderia dispensar a instauração de processo administrativo disciplinar, se não houvesse previsão infraconstitucional expressa nesse sentido ${ }^{126}$; ou, no caso do chamado poder de polícia, jogando os administrados ao movediço terreno das limitações administrativas à liberdade e à propriedade sem garantia processual alguma.

Se o ato administrativo viciado ensejou benefício para o administrado, é inegável que a desconstituição desse efeito induz a potencial situação de litigância, obrigando incondicionalmente à Administração a realizar do devido processo legal administrativo e, por conseguinte, uma de suas faces essenciais, o amplo contraditório.

Quando o ato administrativo de invalidação tem por efeito desconstituir efeito favorável ao administrado, ele assume a natureza de provimento ablatório, fazendo-se indispensável ao princípio do contraditório ${ }^{127}$.

Além do mais, assim prescreve a LFPA:

"Art. 28. Devem ser objeto de intimação os atos do processo que resultem para o interessado em imposição de deveres, ônus, sanções ou restrições ao exercício de direitos e atividades e os atos de outra natureza de seu interesse."

125 Ver STF, RE 158439-RS, Rel. Min. Marco Aurélio, Segunda Turma, julgado em 30.08 .94 (apud Lúcia Valle Figueiredo, Curso..., cit., p. 411); STJ, ROMS n 10123-RJ, Rel. Min. Demócrito Reinaldo, Primeira Turma, maioria pelo não provimento, julgado em 15.06.99, publicado no DJ de 27.09.99; STJ, MS n 6313-DF, Rel. Min. Garcia Vieira, Primeira Seção, maioria pela concessão da segurança, julgado em 27.10.99, publicado no DJ de 17.12.99; STJ, RESP n 12406-RS, Rel. Min. Edson Vidigal, Quinta Turma, unânime pelo provimento, julgado em 17.12.98, publicado no DJ de 01.03.99; e STJ, ROMS n 9554-CE, Rel. Min. Vicente Leal, Sexta Turma, unânime pelo provimento, julgado em 17.12.98, publicado no DJ de 17.02.99.

126 Ver Lei $n^{\circ} 8.112 / 90$, art. 146.

127 Cf. Lúcia Valle Figueiredo, Curso..., cit., pp. 158-159. 
Ainda que o ato viciado implique em forte prejuízo ao interesse público, deve a Administração comunicar ao administrado a existência do vício e a iminência do ato administrativo de invalidação. A notificação prévia do administrado quanto ao to administrativo de invalidação, representa também o exercício da prerrogativa administrativa de invalidar, impedindo a decadência desta ${ }^{128}$. Mesmo nos casos de violenta quebra do regime jurídico-administrativo, vemos que o contraditório representa uma medida preventiva para a própria Administração, permitindo-lhe melhor harmonizar as situações jurídicas produzidas em boa fé às exigências de restauração da juridicidade. Lembrando ainda a assertiva de Mônica Martins Toscano ${ }^{129}$.

"Por intermédio do princípio do contraditório e ampla defesa concede-se ao administrado não apenas o direito de expor sua versão acerca do fato sobre o qual versa o procedimento, como também exigir da Administração que esgote todas as fases do procedimento até a produção do ato administrativo final."

Como o regime jurídico-administrativo é regido pelo princípio da prevalência do interesse público sobre o interesse privado, caso a mínima permanência do ato viciado eficaz comprometa, de alguma forma, o interesse público in concreto, é possível à Administração suspender os efeitos do ato invalidável, até o encerramento do processo administrativo de invalidação. Isso permitirá a administração, simultaneamente, resguardar o interesse público e proteger o interesse legítimo do administrado de boa-fé, quando no exercício da prerrogativa administrativa de invalidar.

Essa providência é assegurada pela própria LFPA, em seu art. 45:

“Art. 45. Em caso de risco iminente, a administração pública poderá motivadamente adotar providências acauteladoras sem a prévia manifestação do interessado".

Observe-se que aqui, confere-se à Administração o dever-poder de adotar medida cautelar em defesa do interesse público, configurado o risco iminente e, desde que regularmente fudamentada. Em princípio, inexiste discricionariedade administrativa na adoção dessa providência cautelar, haja vista a lei vincular o seu exercício a um termo jurídico indeterminado ou fluido. Os chamados "conceitos jurídicos indeterminados", a nosso ver, somente ensejarão o emprego do binômio conveniência-oportunidade quando a interpretação destes diante do caso concreto for insuficiente para fazer cessar sua fluidez significativa ${ }^{130}$. Recorde-se ainda que a LFPA ${ }^{131}$ determina que a motivação deve ser explícita, clara e congruente, podendo consistir

128 Ver LFPA. art. $54, \S 2^{\circ}$.

129 Op. cit., p. 218 (grifamos).

130 Cf. Vladimir da Rocha França, "Fundamentos...", cit., pp. 72-73; e idem, Invalidação..., cit., pp. 97-108.

131 Art. $50, \S 1^{\circ}$. 
em declaração de concordância com fundamentos de anteriores pareceres, informações, decisões ou propostas, que, neste caso, serão parte integrante do ato.

Se Administração tem a prerrogativa de invalidar, porque lhe negar o poder de suspender a eficácia jurídica do ato portador de vício afim de aferir as situações jurídicas constituídas de boa fé sem prejudicar o interesse público? Mas não se deve perder de vista que essa medida tem caráter excepcional, somente podendo haver recurso a esta se obedecidos os requisitos fixados pela própria LFPA.

Algumas situações justificam essa medida cautelar no caso do ato viciado eficaz: quando declarada a inconstitucionalidade da lei ou ato normativo que serviu de pressuposto jurídico para expedição do ato invalidável; quando o vício consistir em quebra de princípio jurídico da administração pública; e, por fim, quando os efeitos do ato portador de vício comprometerem decisivamente o erário público e não se tratar de prestação de natureza alimentar.

Caso o ato viciado eficaz trate de medida que beneficie a remuneração de servidor público ou o provento do administrado, fica impedida a suspensão de seus efeitos, a não ser que o favor legal implique em quebra de preceito constitucional ${ }^{132}$.

Se a invalidação administrativa representar a inteira desconstituição dos efeitos nessa matéria, ou seja, a extinção total da remuneração ou do provento, imprescindível se faz o contraditório. É a saída mais prudente no nosso entendimento.

Nos atos invalidáveis que ainda padecem de ineficácia, não há o que se falar em suspensão de seus efeitos, haja vista o regime jurídico-administrativo já impedir a eclosão destes. Aqui, deve a Administração realizar o contraditório, inexistindo qualquer prejuizo que possa justificar a imediata invalidação do ato sem a ouvida do interessado, especialmente em se tratando de ato vinculado. Se efeito nenhum foi produzido, direito algum foi incorporado no patrimônio do particular, bem como, qualquer prejuízo iminente se configura.

Havendo a regular suspensão da eficácia jurídica do ato invalidável, deve a Administração comunicar a medida ao administrado e as razões de sua implementação ${ }^{133}$ portanto, não deixa de haver respeito ao contraditório, podendo o administrado pedir a tutela jurisdicional se entender abusiva a medida cautelar.

Mediante o contraditório, a Administração reduz os riscos de sua responsabilização por perdas e danos aos administrados, ou mesmo, o prejuízo a ser recomposto em prol dos princípios da moralidade, proporcionalidade e isonomia. O contraditório não existe para "atrapalhar" ou "burocratizar" a ação administrativa, mas sim para conceder-lhe segurança e proporcionalidade, democratizando a própria administração pública. Nunca deve ser esquecido que a cidadania e a dignidade da pessoa humana são fundamentos de nosso Estado de Direito ${ }^{134}$.

Não observado o princípio do contraditório no procedimento que precede o ato administrativo de invalidação, este passa a padecer de vício quanto ao seu requisito

132 Ver CF, art. 37, XI e XV, e $\$ 10$; art. 40 e $\S ;$ e 201 e ss.

133 Ver LFPA, art. 28.

134 Ver CF, art. $1^{\circ}$, I e III. 
procedimental ${ }^{135}$ Afinal, todo ato administrativo é sujeito a um mesmo conjunto de pressupostos de validade ${ }^{136}$.

\section{4 - Sobre os requisitos da intimação}

O contraditório no processo administrativo de invalidação se forma a partir da intimação do administrado que será atingido pelo seu ato final.

A intimação do administrado, em qualquer caso, para tomar ciência da situação, deve conter ${ }^{137}$ : a identificação do intimado e do órgão que implementará a medida; a finalidade da intimação, bem como a data, hora e local em que deve comparecer, caso seja necessário a sua audiência; a informação da continuidade do processo independentemente de seu comparecimento; e, por fim, a devida e clara indicação dos fatos e fundamentos jurídicos que sustentam a iminência do ato administrativo de invalidação.

A LFPA $^{138}$ determina que a intimação deve observar a antecedência mínima de três dias úteis quanto à data de comparecimento do administrado ou de seu representante, para aduzir o que entender devido. Caso o prazo mínimo, em virtude da complexidade da situação, seja insuficiente para permitir a eficiente defesa do interessado, deve a Administração fixar prazo maior, em homenagem ao amplo contraditório $^{139}$.

Pode a Administração cientificar o interessado por via postal com aviso de recebimento, por telegrama ou por qualquer outro meio que assegure a certeza da comunicação dos termos do processo ${ }^{140}$. Prescreve ainda a LFPA ${ }^{141}$ que no caso de interessados indeterminados, por desconhecimento ou por imprecisão no domićlio, a intimação deve ser feita pelo diário oficial.

Quando não observados tais requisitos, a intimação é nula e ausente está o contraditório. Entretanto, a LFPA ${ }^{142}$ determina que o comparecimento do administrado supre a sua falha ou irregularidade.

Outro ponto relevante é que o desatendimento da intimação regular não importa em reconhecimento da verdade dos fatos nem a renúncia a direitos pelo administrado, mantendo-se no curso do processo o direito de ampla defesa do interessado ${ }^{143}$. Isso

135 Cf. Mônica Martins Toscano, op. cit., pp. 226-230; Carlos Ari Sundfeld, "A Importância...", cit., p. 66; Celso Antônio Bandeira de Mello, op. cit., p. 286; e Lúcia Valle Figueiredo, Curso..., cit., pp. 177-178.

136 Lúcia Valle Figueiredo, Curso..., cit., p. 226.

137 Ver LFPA, art. 26, $\S 1^{\circ}$, I a VI.

138 Ver arts. $26, \S 2^{\circ}$; e 39 , caput.

139 Cf. Lúcia Valle Figueiredo, Curso..., cit., p. 411.

140 Ver LFPA. art. $26, \S 3^{\circ}$.

141 Ver art. 26, $\$ 4^{\circ}$. Ver STF, RE $n^{\circ}$ 157905-SP, Rel. Min. Marco Aurélio, Pleno, unânime pelo movimento, julgado em 06.08.97, publicado no DJ de 25.09.98.

142 Ver art. $26 \S 5^{\circ}$.

143 Ver LFPA. art. 27, e parágrafo único. 
permite que o administrado possa tranqüilamente recorrer às vias judiciais para preservar o seu direito ameaçado, caso assim entender melhor ${ }^{144}$.

Pela lição de Lúcia Valle Figueiredo ${ }^{145}$, direito ao silêncio é uma prerrogativa constitucional:

“(...) ao administrado não podem ser carreadas quaisquer restrições ou agravamento da sanção por ter permanecido em silêncio".

Vejamos mais um preceito da LFPA:

Art. 39. (...)

Parágrafo único. Não sendo atendida a intimação, poderá o órgão competente, se entender relevante a matéria, suprir de ofício a omissão não se eximindo de proferir a decisão".

Poderia a Administração invalidar imediatamente o ato, após a recusa do administrado em atender a intimação? A Administração deve dar continuidade ao processo administrativo de invalidação, determinando a instrução necessária para a tomada de decisão que melhor se ajuste ao interesse público. O princípio da oficialidade integra o devido processo legal administrativo, determinando que a mobilização do processo administrativo, uma vez desencadeado de ofício ou por instigação do interessado, é encargo da própria Administração, a não ser que o objeto do mesmo seja a ampliação da esfera de direitos do administrado ${ }^{146}$.

Impede a LFPA que o silêncio intencional do administrado possa ser considerado pelo órgão competente como motivo habil para fundamentar o ato administrativo de invalidação. Caso a Administração tenha os elementos necessários para a tomada da decisão de desconstituir o ato invalidável e este tenha gerado benefício para o administrado que, regularmente intimado silencia sobre os fundamentos fáticos e jurídicos levados em consideração para o provimento administrativo, nada a impede de expedir o ato administrativo de invalidação. Entretanto, ressalte-se, se os elementos que a autoridade administrativa considera suficientes para o provimento foram devidamente comunicados ao administrado. Não há nessa exegese quebra alguma do amplo contraditório.

Caso outro elemento surja, no curso da instrução e após a intimação, que reforce a opção pelo provimento de invalidação, deve haver sua comunicação ao administrado, sob pena de nulidade do ato resultante do processo.

\section{5 - Considerações finais}

A investigação do amplo contraditório na invalidação administrativa representa um ponto sensível na compreensão do regime jurídico-administrativo. A interpreta-

144 Ver CF, art. $5^{\circ}, \mathrm{XXXV}$.

145 Curso..., cit., p. 419.

146 Celso Antônio Bandeira de Mello, op. cit., p. 364. 
ção das prerrogativas legalmente concedidas à Administração de modo algum pode sonegar a cognição dos princípios jurídicos que a regem.

O amplo contraditório é requisito essencial para a invalidação administrativa, quando o ato invalidável produziu efeito favorável ao administrado. Se o mesmo ingressa de boa fé na órbita de vigência do ato viciado e não concorreu para o seu vício, parece-nos inconcebível que o regime jurídico-administrativo nenhuma garantia lhe conceda para preservá-la.

E sem o contraditório, defesa alguma é possível.

Fere princípios essenciais do regime juridico-administrativo invalidação administrativa sem o amplo contraditório. Negar-lhe tal direito seria uma afronta ao preceito constitucional tão caro do devido processo legal administrativo.

Com essas considerações, tentamos identificar uma rota possível para que Administração possa navegar na juridicidade e corrigir seus rumos quando necessário, sem entretanto causar constrangimentos ao administrados inteiramente desnecessários para o alcance do interesse público. Quantas situações de indenização poderiam ter sido evitadas pelo Poder Público com medida tão singela e, ao mesmo tempo, imprescindível para o regular seguimento da ação administrativa.

Nada impede ao administrado o imediato recurso ao Poder Judiciário, caso renuncie às vias administrativas. É inafastável o controle judicial da Administração quando ameaça ou lesão à direito individual é argüída junto aos órgãos jurisdicionais. $O$ rol de direitos e garantias instrumentais no âmbito da administração pública federal estão a disposição dos administrados, cabendo-lhe a discrição de exercê-los ou não.

$O$ estudo aqui se encerra com a ingênua esperança de que essas linhas, de alguma forma, possam ter contribuído para a discussão sobre a matéria. Incitar o debate é o máximo que pode um aprendiz do direito público tentar fazer. 